\title{
The decreasing importance of acidification episodes with recovery from acidification: an analysis of the 30-year record from Birkenes, Norway
}

\author{
R. F. Wright \\ Norwegian Institute for Water Research, Gaustadallèen 21, 0349 Oslo, Norway \\ Received: 23 October 2006 - Published in Hydrol. Earth Syst. Sci. Discuss.: 11 September 2007 \\ Revised: 3 December 2007 - Accepted: 5 February 2008 - Published: 5 March 2008
}

\begin{abstract}
The 30-year record 1975-2004 of weekly samples of streamwater chemistry from Birkenes, Norway, shows 106 acid episodes below the threshold of ANC $-50 \mu \mathrm{eq} 1^{-1}$. The frequency, severity and duration of episodes have diminished since about 1990 due to chemical recovery following reduced deposition of sulphur. In particular $\mathrm{SO}_{4}$-driven episodes in the first runoff following drought have become less intense and less frequent, whereas episodes driven by climate (wind, high flow) continue. The data show significant empirical relationships between strength of the driver, degree of chemical recovery, and severity of ANC depression.
\end{abstract}

\section{Introduction}

Long-term deposition of sulphur and nitrogen compounds from the atmosphere has caused widespread acidification of sensitive freshwaters (Overrein et al., 1980). Acidification is often characterised by chronic low $\mathrm{pH}$ and acid neutralising capacity (ANC) with elevated concentrations of inorganic aluminium species $\left(\mathrm{Al}^{n+}\right)$. Superimposed on the chronic acidification are acid episodes, often defined as short-term decrease of $\mathrm{pH}$ or ANC (Wigington et al., 1992). The acid episodes are of particular interest as they can cause acute biological damage, especially in streams. Episodes in lakes are less prominent because the volume of water in the lake damps the response to episodic inputs.

In Norway investigations of the causes of acid episodes began in the 1970s prompted by a fish kill in association with snowmelt in 1975 (Leivestad and Muniz, 1976). Studies were made of episodes caused by snowmelt (Skartveit and Gjessing, 1979; Johannessen et al., 1980). Acid episodes during snowmelt have also been extensively investigated in streams in northern Sweden (Laudon and Bishop, 1999).

Correspondence to: R. F. Wright

(richard.wright@niva.no)
Acid runoff following summer drought has been studied in Norway (Christophersen et al., 1982) and in Ontario, Canada (Dillon et al., 1997). In near coastal areas acid episodes can be driven by seasalt deposition (Skartveit, 1982; Hindar et al., 1994). High discharge can also cause acid episodes (Mulder et al., 1995). In the late 1980s the United States Environmental Protection Agency (US EPA) conducted a comprehensive project (Episodic Response Project) on acid episodes in 13 streams in the northeastern United States (Wigington et al., 1996).

Since the mid-1980s deposition of S and N (mostly S) has decreased substantially in most parts of Europe and eastern North America as a result of national measures and international agreements to reduce the emissions of acid precursors (UNECE, 1999). Surface waters in these regions have begun to recover; chemical conditions have improved and in some cases biological recovery has been observed (Evans et al., 2001; Skjelkvåle et al., 2003).

The goals of this work are to (1) determine the dominant causes of acid episodes at Birkenes, (2) assess the role of climate as a driver of acid episodes, and (3) assess the changes in frequency, severity and duration of episodes during the process of recovery. The aim is to search for simple empirical relationships that can be used to predict the severity and duration of episodes as the catchment recovers from acidification in the future. The analysis was carried out for the small catchment at Birkenes, Norway, which has a 30-year record of streamwater discharge and chemistry, bulk deposition volume and chemistry, and meteorological data from nearby stations.

\section{Materials and methods}

Birkenes is a $0.41-\mathrm{km}^{2}$ coniferous-forested catchment located about $20 \mathrm{~km}$ from the south coast of Norway. The site is characterised by thin podsols and brown earth soils

Published by Copernicus Publications on behalf of the European Geosciences Union. 
developed on patchy moraine of granitic mineralogy overlying biotite granite. The climate at Birkenes is maritime, with annual precipitation about $1400 \mathrm{~mm}$ and runoff about $1200 \mathrm{~mm}$. Winters are often characterised by frequent snowmelt periods. Deposition of seasalts at Birkenes is relatively high (1974-2004 mean bulk deposition of $\mathrm{Cl}$ $94 \mathrm{meq} \mathrm{m}^{-2} \mathrm{yr}^{-1}$ ) due to the proximity to the coast.

Birkenes has been a research and monitoring site since 1972 and is part of the Norwegian programme for monitoring long-range transported air pollution (SFT, 2006). Discharge is measured by the Norwegian Water Resources and Electricity Board with a level recorder and a V-notch weir and reduced to mean daily discharge. Starting July 1972 samples for determination of chemical composition of runoff have been taken weekly (daily until December 1974) by the Norwegian Institute for Water Research (NIVA). No samples were collected in 1979 and 1984. Samples were analysed at NIVA for major ions using routine, accredited methods (SFT, 2006). Prior to May 1974 only $\mathrm{pH}, \mathrm{Ca}, \mathrm{SO}_{4}$ and $\mathrm{NO}_{3}$ plus either $\mathrm{Na}$ or $\mathrm{Cl}$ were determined, and thus ANC cannot be calculated for these samples. The record from July 1972December 2004 comprises 2293 water chemistry samples.

Samples for volume and chemical composition of bulk precipitation and air were collected daily beginning July 1972 by the Norwegian Institute for Air Research (NILU) (Aas et al., 2004). Samples were analysed at NILU for major ions using routine, accredited methods. During the first years not all major ions were measured; Ca measurements began in 1974, $\mathrm{Na}$ and $\mathrm{K}$ in 1986, and $\mathrm{Cl}$ in 1980.

Meteorological data came from nearby stations operated by the Norwegian Meteorological Institute. Daily data for precipitation amount come from station 38450 Herefoss and for temperature from 39690 Byglandsfjord. These stations are located $<20 \mathrm{~km}$ distant and at approximately the same elevation as Birkenes. Derived parameters such as Palmer drought index were kindly provided by the Norwegian Meteorological Institute.

The ability of the weekly sampling interval to capture episodes was evaluated on the basis of the 2-year record of daily water chemistry determinations for several parameters (July 1972-November 1974). The autocorrelation was computed for time lags of 1-30 days. Also the extreme value of each parameter (2nd or 98th percentile) was calculated for subsets of the data comprising samples collected at 1-14 day intervals.

ANC was used as the measure of acidification. ANC is a calculated parameter defined as the equivalent difference between sum of base cations $(\mathrm{Ca}+\mathrm{Mg}+\mathrm{Na}+\mathrm{K})$ minus sum of strong acid anions $\left(\mathrm{SO}_{4}+\mathrm{Cl}+\mathrm{NO}_{3}\right)$ (Reuss and Johnson 1986). Changes in ANC can thus be readily assigned to changes in concentrations of specific ions (Wigington et al., 1996). The concentrations of the various ions, especially the strong acid anions, are closely related to key sources and biogeochemical processes operating in soil and surface waters.
Relationships between ANC and discharge were based on daily mean discharge measurement for the day of the chemical sample (generally once a week). Results were grouped into 5-year periods beginning with 1975 . Because no samples were collected in 1979 and 1984, the periods 1975-1979 and 1980-1984 had data for only 4 years.

Acid episode was defined as a short-term decrease in ANC (Wigington et al., 1996). This definition requires specification of an ANC threshold below which the episode occurs. A threshold of ANC $<-50 \mu \mathrm{eq}^{-1}$ was used as the criterion for an episode at Birkenes. This level was chosen such that the majority of the samples were above the threshold; it has no inherent biological significance. The operational definition of Wigington et al. (1996) was used to identify episodes relative to this threshold. Namely, the start of an episode was taken as the date at which the ANC fell below $-50 \mu \mathrm{eq} 1^{-1}$, the duration as the number of weeks during which the ANC remained below $-50 \mu \mathrm{eq} \mathrm{l}^{-1}$, and the end of the episode as the date at which the last sample had ANC below $-50 \mu \mathrm{eq} 1^{-1}$. The severity of the episodes was classed relative to two further thresholds, $\mathrm{ANC}<-75$ and $<-100 \mu \mathrm{eq} 1^{-1}$. The difference in ANC between the sample before the episode and the minimum reached during the episode is termed "delta ANC". Episodes with delta ANC $<-5 \mu$ eq $1^{-1}$ were excluded.

Assignment of the major ion driver causing each episode was based on the difference in concentration of major ions in the sample with minimum ANC measured during the episode minus the concentration in the sample collected immediately prior to the onset of the episode. By definition a decrease in ANC must be due to decrease in one or more base cation or increase in one or more strong acid anion, or a combination of both. The individual ion contribution to each episode was calculated as a percentage. Each episode was assigned to one of four main drivers: direct influence of precipitation (termed here "hydrology" and indicated by decrease in base cation concentrations, due mostly to a dilution of $\mathrm{Ca}$ ), summer drought $\left(\mathrm{SO}_{4}\right.$ peak), snowmelt $\left(\mathrm{SO}_{4}+\mathrm{NO}_{3}\right.$ peaks $)$, and seasalt deposition ( $\mathrm{Cl}$ peak). Much of the analysis followed the procedures used by Evans et al. (2008).

\section{Results}

Autocorrelation with time lag of 1-30 days for the water samples collected daily in 1972-1974 showed that for the parameters $\mathrm{pH}, \mathrm{H}^{+}, \mathrm{SO}_{4}, \mathrm{NO}_{3}$, and $\mathrm{Ca}$ the concentrations were significantly correlated (95\% confidence bounds) at time steps less than about 18 days. Discharge, on the other hand, was significantly autocorrelated only at time lags less than 5 days. For a 7-day time lag the correlation coefficients ranged from 0.54 for $\mathrm{H}^{+}$to 0.67 for $\mathrm{SO}_{4}$ and $\mathrm{Ca}$, whereas only 0.13 for discharge. Also the 98 th percentile concentration varied by less than $5 \%$ for sampling intervals of 14 days or less. These results indicate that weekly sampling 

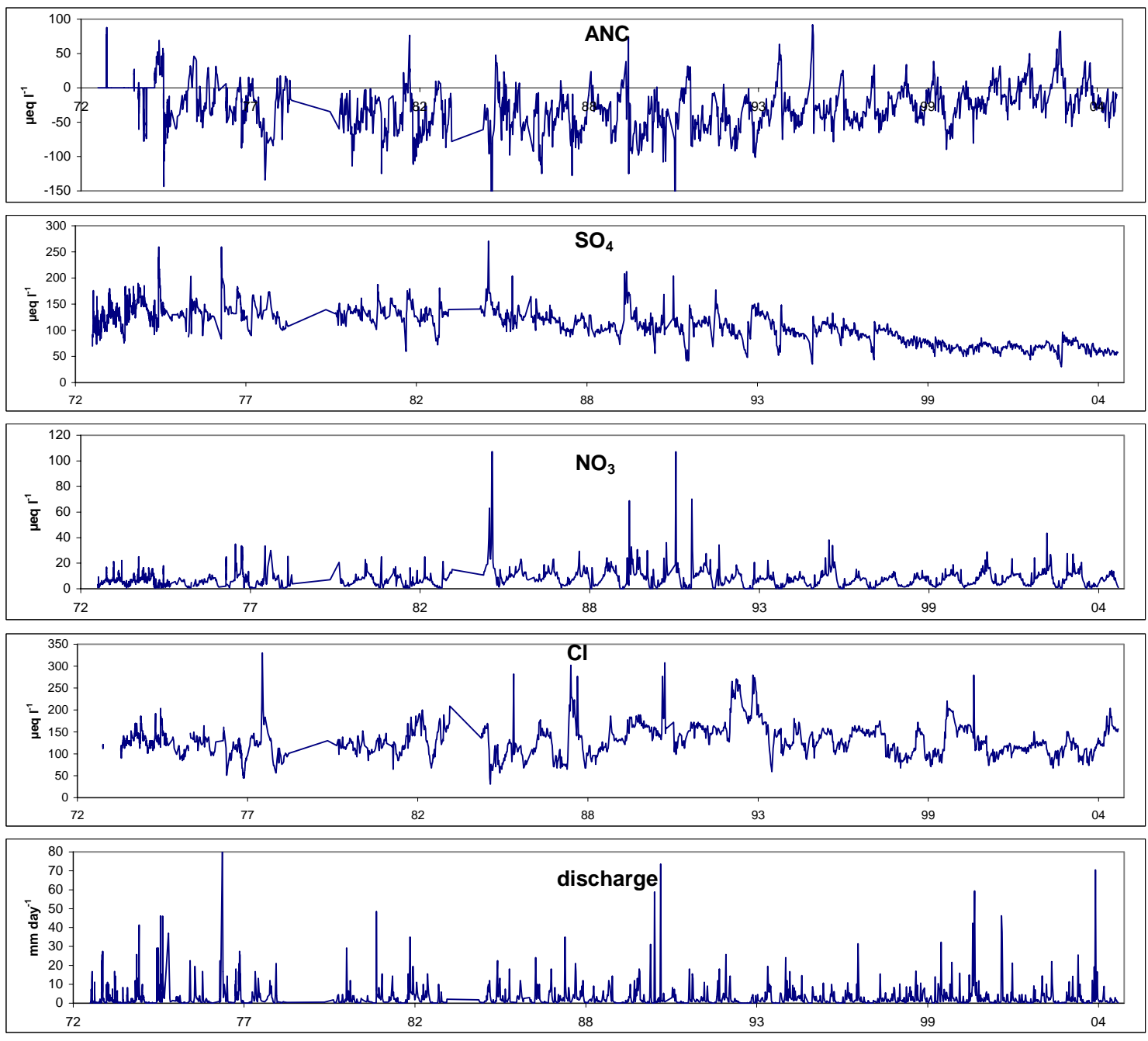

Fig. 1. ANC, concentrations of $\mathrm{SO}_{4}, \mathrm{NO}_{3}$, and $\mathrm{Cl}$ and discharge of streamwater at Birkenes, Norway, over the period 1972-2004. Data for the years 1979 and 1984 are lacking; measurements for several of the major ions are lacking for samples collected prior to 1975.

is sufficient to capture episodes at Birkenes, and in particular the severe episodes of several weeks duration with large delta ANC. Weekly sampling, of course, is insufficient to detect the absolute minimum ANC (or $\mathrm{pH}$ ) during an episode.

The time series of ANC in runoff at Birkenes shows marked and at times frequent episodes of low ANC concurrent with peaks in the major four drivers (Fig. 1). The record also shows clear improvement in water quality from about 1990, with decreasing concentrations of $\mathrm{SO}_{4}$ and increasing ANC (Fig. 2). The minimum ANC recorded during episodes has gradually increased in parallel with the general increase in mean ANC (Fig. 3). October 1993 was the last time ANC decreased to below $-100 \mu \mathrm{eq} 1^{-1}$, and November 2000 was the last time ANC decreased to below $-75 \mu \mathrm{eq}^{-1}$. Over the period 1975-2004 a total of 106 episodes with ANC $<-50 \mu \mathrm{eq} 1^{-1}$ were identified, of which 54 reached $\mathrm{ANC}<-75 \mu \mathrm{eq}^{-1}$ and 14 reached $\mathrm{ANC}<-100 \mu \mathrm{eq} \mathrm{l}^{-1}$.
High flow episodes. ANC typically drops during high discharge events. These episodes are characterised by dilution of base cations, mainly $\mathrm{Ca}$. $\mathrm{Ca}$ comes principally from weathering of soil minerals and secondarily from atmospheric deposition; the volume-weighted mean concentration of $\mathrm{Ca}$ in runoff 1975-2003 was $45 \mu \mathrm{eq} \mathrm{l}^{-1}$, whereas bulk precipitation had only $8 \mu \mathrm{eq} 1^{-1}$. The hypothesised mechanism is that soil solution in the upper mostly organic soil layers has lower concentrations of base cations because of lower rates of chemical weathering relative to soil solution in the lower mineral soil. At high flow a larger proportion of runoff comes from the base-cation poor upper soil, and in addition is diluted by Ca-poor precipitation (Christophersen et al., 1982).

Regressions of ANC on discharge for samples collected during 5-year time blocks yield significant relationships $(\mathrm{p}<0.001)$, with lower ANC at high flow (Table 1). The regression lines for successive 5-year blocks are roughly 


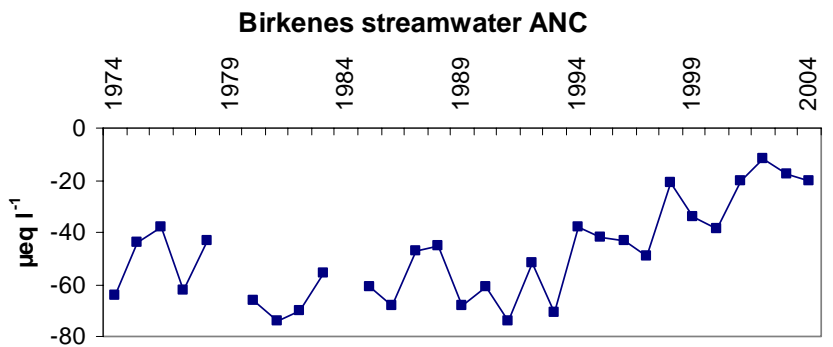

Fig. 2. Volume-weighted annual average $\mathrm{ANC}\left(\mu \mathrm{eq} 1^{-1}\right)$ in runoff at Birkenes 1974-2004.

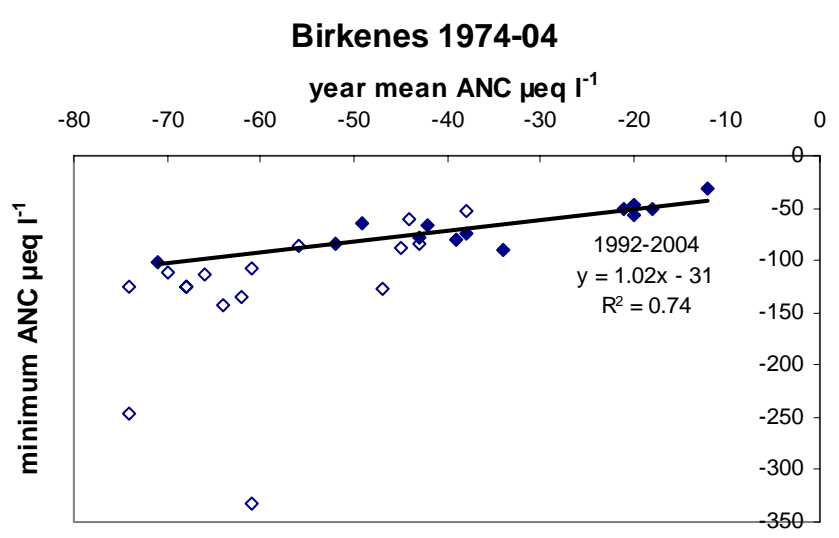

Fig. 3. Relationship between mean volume-weighted yearly ANC and minimum ANC ( $\mu$ eq $\left.1^{-1}\right)$ in runoff at Birkenes 1974-2004. The regression is based on the years 1992-2004.

parallel but at slightly higher ANC (Fig. 4). ANC at high flow (98th-percentile) is higher in the period 2000-2004 relative to earlier periods (Fig. 5). The trend over time in ANC at high flow reflects the general recovery trend for annual volume-weighted mean ANC in runoff at Birkenes.

Grouping of the samples into those at low flow (Q below 25th percentile) and those at high flow (Q above 75th percentile) indicates that the lower ANC at high flow is mainly due to dilution; about half of the decrease can be accounted for by lower concentrations of $\mathrm{Ca}$ at high flow (Table 2, Fig. 6). This has apparently not changed significantly over time, although the role of $\mathrm{SO}_{4}$ is diminished in the later period because of lower concentrations of $\mathrm{SO}_{4}$ in deposition and runoff.

Summer drought episodes. The first runoff following summer drought consistently has an elevated concentration of $\mathrm{SO}_{4}$ and a markedly lower ANC. The mechanism is probably the reduction of $\mathrm{SO}_{4}$ and storage as reduced $\mathrm{S}$ in anoxic parts of the soil during dry periods with the subsequent reoxidation and flushing out of $\mathrm{SO}_{4}$ with the first runoff (Dillon et al., 1997). Acid cations $\left(\mathrm{H}^{+}\right.$and $\left.\mathrm{Al}^{n+}\right)$ comprise a fraction of the accompanying cations and thus ANC decreases. At Birkenes the onset of autumn rain has been late August or September in most years.
Table 1. Linear regression of ANC ( $\mu \mathrm{eq} 1^{-1}$ ) on log discharge $(\mathrm{mm} /$ day) for samples collected during 5-year time blocks at Birkenes. $\mathrm{n}=$ number of samples. All regressions are significant at $\mathrm{p}<0.001$ level.

\begin{tabular}{lllll}
\hline period & $\mathrm{n}$ & slope & intercept & $\mathrm{r}^{2}$ \\
\hline $1975-1979$ & 215 & -21.4 & -23.2 & 0.32 \\
$1980-1984$ & 190 & -35.9 & -37.4 & 0.37 \\
$1985-1989$ & 238 & -28.1 & -40.2 & 0.23 \\
$1990-1994$ & 245 & -23.2 & -42.9 & 0.32 \\
$1995-1999$ & 257 & -19.3 & -24.2 & 0.25 \\
$2000-2003$ & 210 & -29.1 & -7.5 & 0.45 \\
\hline
\end{tabular}

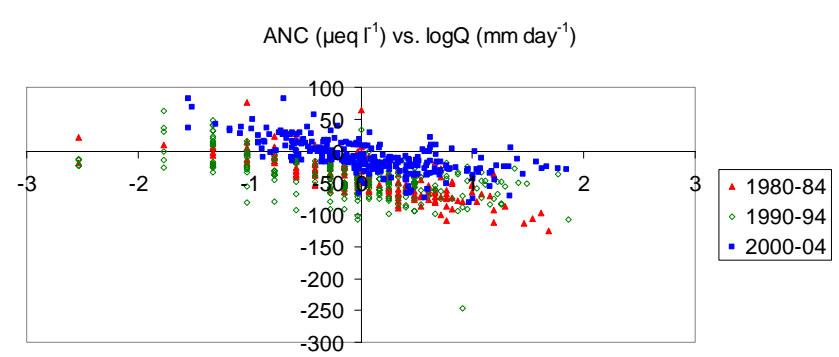

Fig. 4. Scatter plot of ANC $\left(\mu \mathrm{eq} 1^{-1}\right)$ on log discharge $\left(\mathrm{mm} \mathrm{day}^{-1}\right)$ for samples from three 5-year periods at Birkenes (1980-1984, 1990-1994 and 2000-2004).

The discharge record for Birkenes shows three general periods of pronounced summer drought: 1974-1977, 19811984, and 1989-1997 (Fig. 6). There have been no major droughts during the last 7 years of the record (19982004). The Palmer drought index for the nearby meteorological station also shows these three general periods of summer drought. The increase in $\mathrm{SO}_{4}$ concentration in first runoff following the drought is a function of the severity of the drought (as indicated by the number of days with low flow). A linear least-squares regression model explains about $25 \%$ of the variance. The decrease in ANC is correlated to the increase in $\mathrm{SO}_{4}$ (Fig. 7).

The mean annual $\mathrm{SO}_{4}$ concentration has decreased dramatically since about 1990 . Whereas the severe droughts in the 1970s led to increase in $\mathrm{SO}_{4}$ concentration in first runoff of $100-150 \mu \mathrm{eq} 1^{-1}$, droughts of similar magnitude in the 1990 s led to increase of only $40-60 \mu \mathrm{eq}^{-1}$. It is expected that with the continued decline in mean annual $\mathrm{SO}_{4}$ concentration a severe drought in recent years would cause even less of a peak in $\mathrm{SO}_{4}$, but there have been no major droughts since 1997 and thus this could not be tested.

Snowmelt episodes. In many streams spring snowmelt is often the time of lowest ANC. The first meltwater contains a greatly disproportionate fraction of the dissolved constituents stored in the snowpack (Johannessen and Henriksen, 1978). At sites receiving acid deposition, the first meltwater thus 
Table 2. Arithmetic mean concentrations of ions $\left(\mu \mathrm{eq} \mathrm{l}^{-1}\right)$ contributing to ANC in runoff samples at low flow $(<25$ th percentile) and high flow ( $>75$ th percentile) collected at Birkenes. The data are split into two periods: 1975-1989 and 1990-2003.

\begin{tabular}{|c|c|c|c|c|c|c|c|c|}
\hline & $\mathrm{SO}_{4}$ & $\mathrm{Cl}$ & $\mathrm{NO}_{3}$ & $\mathrm{Ca}$ & $\mathrm{Mg}$ & $\mathrm{Na}$ & $\mathrm{K}$ & ANC \\
\hline \multicolumn{9}{|c|}{ Mean chemistry (all data) } \\
\hline 1975-1989 & 130.9 & 117.7 & 8.4 & 68.8 & 36.4 & 116.5 & 6.7 & -28.7 \\
\hline 1990-2003 & 88.8 & 136.4 & 8.5 & 50.3 & 27.0 & 128.9 & 3.9 & -23.5 \\
\hline \multicolumn{9}{|c|}{ Mean low flow chemistry } \\
\hline 1975-1989 & 120.6 & 122.4 & 5.7 & 82.9 & 36.1 & 120.8 & 6.9 & -2.0 \\
\hline 1990-2003 & 78.1 & 140.0 & 3.7 & 63.6 & 27.6 & 132.1 & 4.4 & 5.8 \\
\hline \multicolumn{9}{|c|}{ Mean high flow chemistry } \\
\hline 1975-1989 & 139.0 & 112.7 & 9.9 & 56.3 & 35.9 & 112.3 & 8.5 & -48.6 \\
\hline 1990-2003 & 89.7 & 130.7 & 11.4 & 38.7 & 25.6 & 123.6 & 4.0 & -39.9 \\
\hline \multicolumn{9}{|c|}{ Mean high flow minus low flow chemistry } \\
\hline & $\Delta \mathrm{SO}_{4}$ & $\Delta \mathrm{Cl}$ & $\Delta \mathrm{NO}_{3}$ & $\Delta \mathrm{Ca}$ & $\Delta \mathrm{Mg}$ & $\Delta \mathrm{Na}$ & $\Delta \mathrm{K}$ & $\triangle \mathrm{ANC}$ \\
\hline 1975-1989 & 18.4 & -9.7 & 4.2 & -26.6 & -0.2 & -8.5 & 1.5 & -46.7 \\
\hline 1990-2003 & 11.6 & -9.3 & 7.7 & -24.8 & -2.0 & -8.5 & -0.4 & -45.7 \\
\hline
\end{tabular}

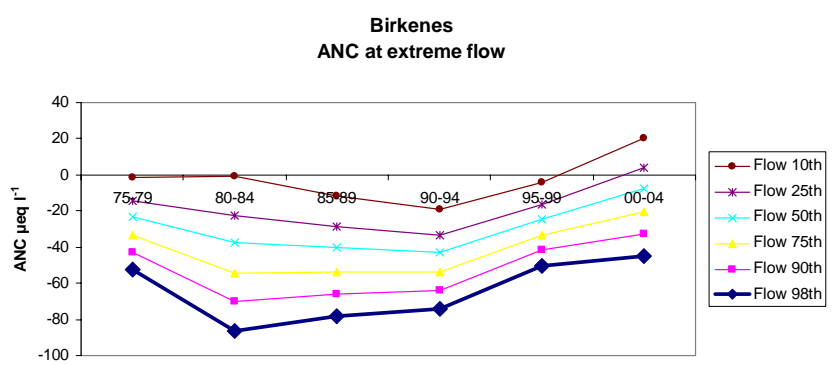

Fig. 5. ANC at various levels of discharge (percentiles of distribution of Q) for samples collected during 5-year intervals at Birkenes. Shown are values obtained from linear regressions of ANC on log Q. Bold line indicates ANC expected at high flow (98th percentile).

contains high concentrations of $\mathrm{SO}_{4}$ and to a lesser extent $\mathrm{NO}_{3}$. The subsequent phases of snowmelt cause dilution of runoff, especially of base cations derived from the soil such as Ca. Chemical changes during spring snowmelt have been extensively studied in northern Sweden (Laudon and Bishop, 1999).

Because Birkenes lies near the south coast and experiences mild winters (for Norway). Mid-winter melting is usual, and thus development of a long-lasting snowpack rarely occurs. Over the 30-year period major spring snowmelt episodes occurred only 4 years. Mid-winter melting episodes were more common, but with much less pronounced in chemical changes in runoff. The most pronounced spring snowmelt occurred in 1985 with peak in $\mathrm{SO}_{4}$ and $\mathrm{NO}_{3}$ concentrations in the first runoff followed by strong dilution as indicated by decrease in $\mathrm{Ca}$ concentration.

www.hydrol-earth-syst-sci.net/12/353/2008/

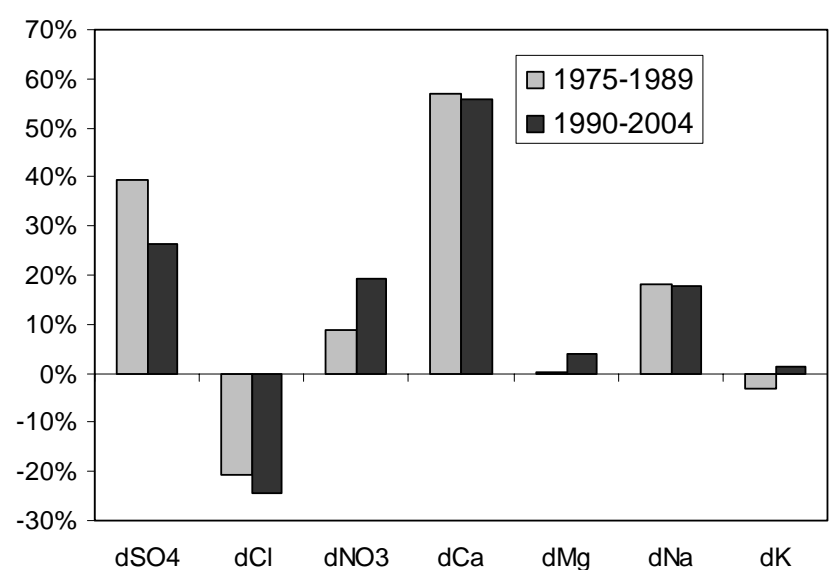

Fig. 6. Contribution of individual ions to decrease in ANC between low flow and high flow (25th and 75th percentile, respectively) in runoff samples collected in 1975-1989 and 1990-2004 at Birkenes.

Seasalt episodes. Storms with high wind and often precipitation cause episodes of high deposition of seasalts to near coastal areas. Subsequent runoff has marked increases in concentrations of $\mathrm{Cl}$ and drop in $\mathrm{ANC}$. The response is due to the differential mobility of $\mathrm{Cl}$ and $\mathrm{Na}$, the major accompanying base cation. While $\mathrm{Cl}$ is quite mobile, Na participates in cation exchange reactions in the soil. A fraction of the $\mathrm{Na}$ (and also $\mathrm{Mg}$ ) is exchanged for acid cations $\mathrm{H}^{+}$and $\mathrm{Al}^{n+}$ on the soil ion-exchange sites.

Due to its proximity to the coast, Birkenes is strongly influenced by seasalt deposition. Volume-weighted mean concentration of $\mathrm{Cl}$ in runoff over the period 1974-2004 was $130 \mu \mathrm{eq} \mathrm{l}^{-1}$. Seasalt deposition is larger during the winter, 

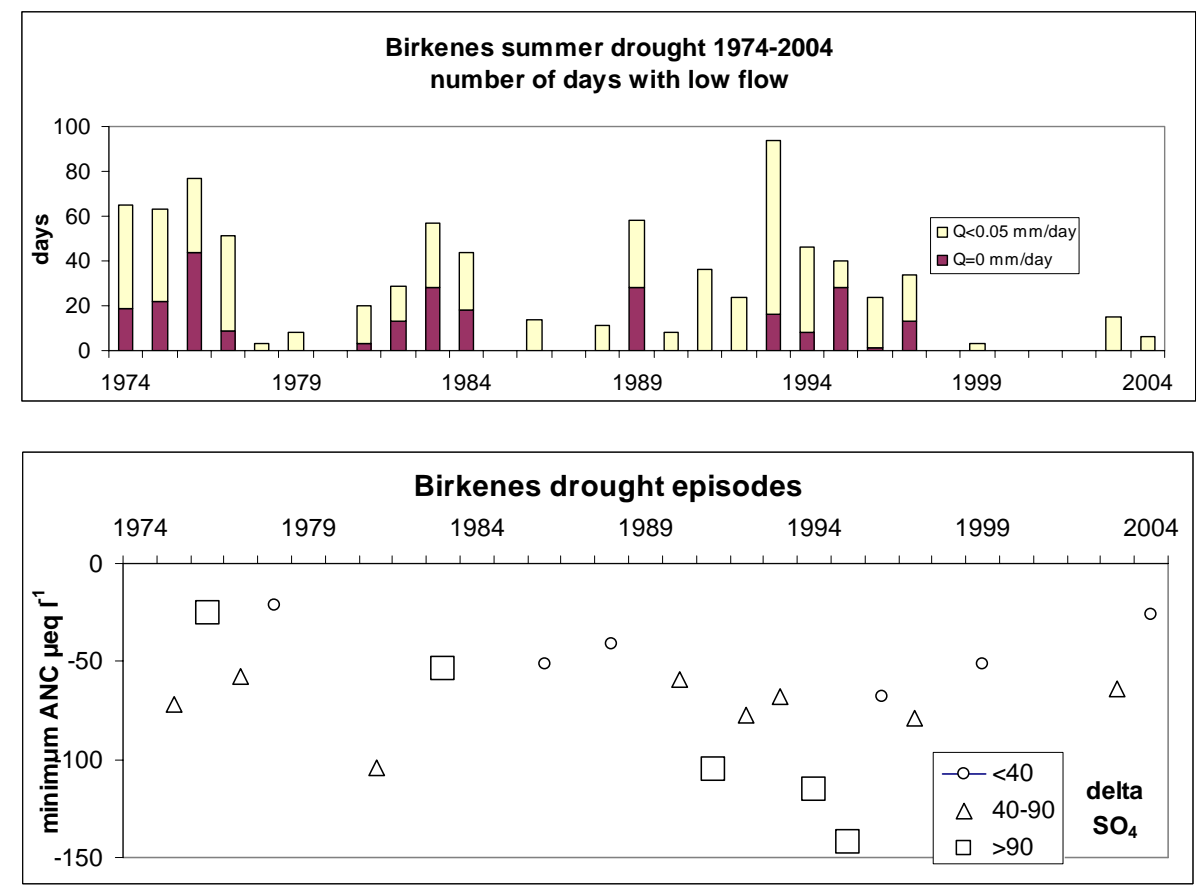

Fig. 7. Birkenes summer droughts. Upper panel: number of days with low flow each year. Dark colour: $0 \mathrm{~mm} / \mathrm{day}$; light colour: $<0.05 \mathrm{~mm} /$ day. Mean daily discharge is about $3.3 \mathrm{~mm} /$ day. Lower panel: Minimum ANC reached in the first runoff following drought, grouped by change in $\mathrm{SO}_{4}$ concentration (delta $=$ after - before). The size and shape of the symbols denote the magnitude of $\mathrm{SO}_{4}$ increase.

due to higher frequency of storms. Seasalt deposition caused 34 of the 93 episodes in which ANC fell below the threshold of $-50 \mu \mathrm{eq} 1^{-1}$ during the period 1980-2004. Particularly large seasalt episodes occurred in October 1990, November 1990, January 1993 and November 2000. January 1993 had the highest deposition of seasalt of any month over the entire record from 1975-2004. At each of these four large seasalt episodes $\mathrm{Cl}$ concentrations in runoff increased by $>80 \mu \mathrm{eq} 1^{-1}$.

During seasalt episodes the decrease in ANC is a function of the increase in $\mathrm{Cl}$ (Fig. 9). Since the general ANC level has increased due to recovery since 1990, a seasalt episode of a given magnitude does not cause ANC to decrease to as low value as early in the record; relative to the ANC threshold of $-50 \mu \mathrm{eq}^{-1}$ seasalt episodes have become less severe (Fig. 9).

Summary of episode frequency, severity and cause. With the threshold of ANC $<-50 \mu$ eq $1^{-1}$ there were 106 episodes during the period 1975-2004. The mean number of episodes per year was highest in the early 1980s ( $>6$ per year) and since the mid-1990s has declined dramatically to $<1$ per year (Fig. 10). Also the severity and duration of the episodes has declined. The role of $\mathrm{SO}_{4}$ in driving ANC depressions has diminished substantially since 1980 (Fig. 11).

\section{Discussion}

The data from Birkenes show that during periods of high flow streamwater is more acidic with lower ANC and higher concentrations of $\mathrm{Al}^{n+}$. The common explanation is that during periods of high flow a larger portion of runoff comes from the upper soil horizons, which have lower stores of base cations and thus lower ANC. In addition high amounts of base cation-poor precipitation cause dilution of base cations in soil water, and the resulting runoff has lower ANC relative to baseflow. At Birkenes this was first modelled in the form of two soil boxes (Christophersen et al., 1982) and later interpreted as mixing of two end-members (precipitation and soil water) with differing water chemistry (Christophersen et al., 1990). A similar conclusion was reached by (Laudon and Bishop 1999) for streams in northern Sweden. A review of acid episodes in Europe conducted by (Davies et al., 1992) concluded that changing flowpaths during hydrological-driven events are of overwhelming importance in determining the chemical character of runoff during episodes.

Acid pulses caused by peaks in $\mathrm{SO}_{4}$ concentrations in the first runoff following summer drought were identified at Birkenes already in the 1970s, and readily simulated by a simple 2-box model (Christophersen and Wright, 1981). The mechanism was thought to be desorption of $\mathrm{SO}_{4}$ in the upper soil horizons. Investigations of $\mathrm{SO}_{4}$ pulses after summer drought in eastern Ontario, Canada, however, showed that the 
Birkenes drought episodes 1974-04
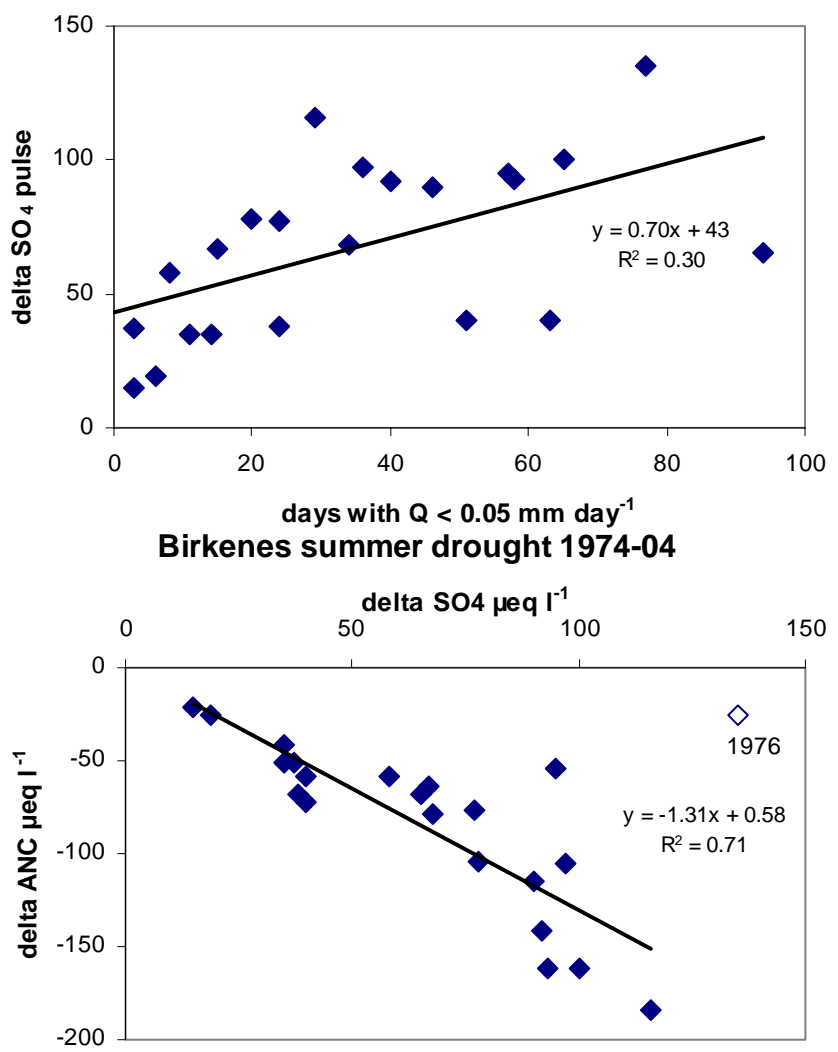

Fig. 8. Summer drought episodes at Birkenes (one per year, but not all years experienced drought). Left panel: Magnitude of the increase in $\mathrm{SO}_{4}$ concentration in first runoff following drought (delta $\mathrm{SO}_{4}$ pulse) in relation to the severity of the drought (indicated by number of days with flow $<0.05 \mathrm{~mm} /$ day). Right panel: Magnitude of the decrease in ANC in relation to the increase in $\mathrm{SO}_{4}$ (year 1976 is excluded from the regression).

phenomenon is likely caused by reduction of $\mathrm{SO}_{4}$ in anoxic zones of wet soils and peatlands during drought followed by oxidation and flushing of previously-reduced sulphur compounds in the first runoff (Dillon et al., 1997). Measurements of the stable isotope ratios of $\delta^{34} \mathrm{~S}$ and $\delta^{18} \mathrm{O}$ in $\mathrm{SO}_{4}$ confirm that the $\mathrm{SO}_{4}$ released is from previously reduced $\mathrm{S}$ (Schiff et al., 2005). Further, at Plastic Lake in Ontario the wetland pool of reduced $\mathrm{S}$ has apparently not been depleted by droughts and is sufficient to cause drought-related $\mathrm{SO}_{4}$ events in the future (Eimers et al., 2006). This is apparently not the case at Birkenes, as the magnitude of the $\mathrm{SO}_{4}$ pulse following drought has diminished in recent years. The stored pool of reduced $S$ is presumably smaller at Birkenes because most of the catchment is comprised of well-drained forest soils. Drought-induced $\mathrm{SO}_{4}$ episodes have also been reported from northern Sweden (Laudon and Bishop, 2002).

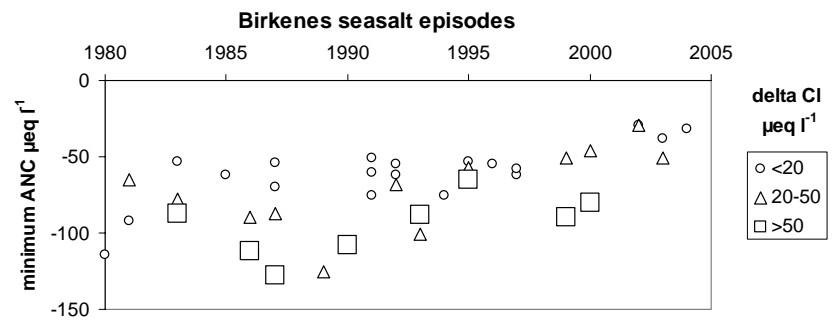

Fig. 9. Seasalt episodes at Birkenes 1980-2004 showing minimum ANC reached during the episodes, grouped by change in $\mathrm{Cl}$ concentration (delta $=$ after - before). The size and shape of the symbols denote the magnitude of $\mathrm{Cl}$ increase.

Snowmelt commonly causes acid episodes in streams and lakes and spring snowmelt is usually the time of the year during which minimum $\mathrm{pH}$ levels are observed. Low $\mathrm{pH}$ and ANC are the result of first the preferential loss of pollutants from the snowpack in the first phases of melt (Johannessen and Henriksen, 1978; Johannessen et al., 1980) and then dilution by the ion-poor meltwater (Johannessen et al., 1980; Laudon and Bishop, 1999; Laudon et al., 2000). Predicting the severity of snowmelt episodes is difficult, although factors such as the amount of acid pollutants stored in the snowpack, rapidity of the melting process and enhancement by rain on snow clear exacerbate the acid depression (Johannessen et al., 1980; Laudon et al., 2000). Due to its proximity to the coast and low elevation, winters at Birkenes are relatively mild, with frequent mid-winter melting. Only during unusually cold winters does a deep and persistent snowpack accumulate. Over the 30-year period 1974-2004 a snowpack with major snowmelt in April occurred only in the mid1980s. Midwinter melting, however, caused ANC depression to $<-50 \mu \mathrm{eq} 1^{-1} 1-2$ times a year during the 1980 s and 1990s, but since 2000 only 1 such episode has occurred.

Seasalt deposition is a major driver of episodic ANC depression at Birkenes. Approximately one-third of all the ANC $<-50 \mu$ eq $1^{-1}$ episodes during the period 1980-2004 were driven primarily by seasalts (Fig. 10). A dramatic seasalt episode in January 1993 caused fish kill in several rivers in southernmost Norway (Hindar et al., 1994). Seasaltdriven acid episodes have been reported from coastal areas of eastern North America (Heath et al., 1992), Scotland (Langan, 1989) and Wales (Neal et al., 1988), and the cationexchange mechanism has been experimentally demonstrated at the catchment scale (Wright et al., 1988).

In response to decreasing levels of sulphur and to a lesser extent nitrogen deposition since the mid-1980s, the general level of acidification at Birkenes has decreased. Volume-weighted annual average ANC levels have increased from $<-70 \mu$ eq $1^{-1}$ to $>-30 \mu$ eq $1^{-1}$, and the severity and duration of episodes has decreased in parallel (Fig. 3). Whereas in the early 1980s the majority of samples had ANC $<-50 \mu \mathrm{eq}^{-1}$, since 2000 most of the samples have 
Birkenes frequency of episodes
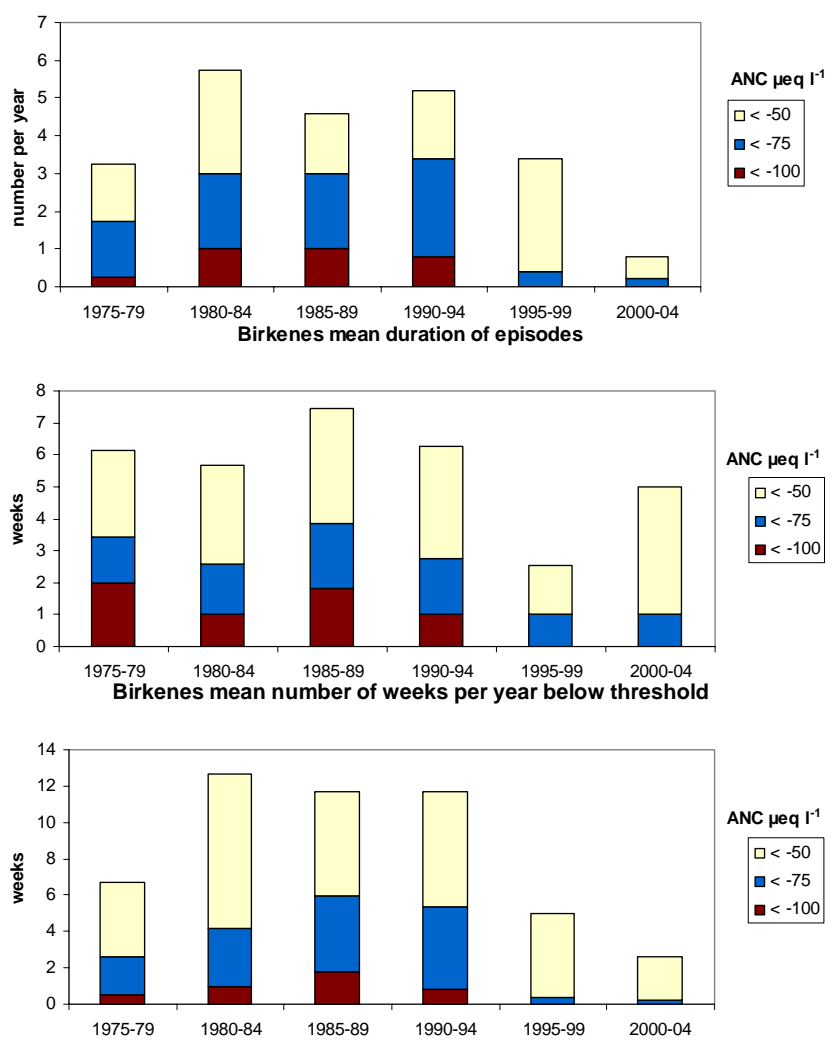

Fig. 10. Summary of episodes with threshold ANC $<-50 \mu \mathrm{eq} 1^{-1}$ at Birkenes 1975-2004 by 5-year period. Upper panel: mean frequency of episodes; middle panel: mean duration of episode; lower panel: mean number of weeks per year below threshold.

$\mathrm{ANC}>-25 \mu \mathrm{eq} 1^{-1}$ (Fig. 1). $\mathrm{SO}_{4}$ is diminishing in importance as a driver of acid episodes at Birkenes, in a similar fashion as found in northern Sweden (Laudon and Bishop, 2002). The drivers high flow and seasalts, however, have not diminished in intensity, and thus caused acid episodes throughout the record, also in recent years.

Several of the causes of acid episodes at Birkenes are clearly related to climate and independent of deposition of $\mathrm{S}$ and $\mathrm{N}$ compounds. Future changes in climate can affect the frequency and severity of episodes. The declining rate of $\mathrm{SO}_{4}$ deposition presumably means that the pool of reduced $\mathrm{S}$ in the soil has decreased during recent years and thus now there is a smaller pool available for oxidation during drought. But there has not been a major drought at Birkenes since 1997. Reduced S might be accumulating in the catchment and a severe acid episode might occur after the next major drought.

Seasalt deposition and seasalt-induced acid episodes are also clearly related to climate. Skartveit (1982) showed that the production rate of seaspray aerosols doubles with each
Birkenes main driver of episodes ANC $<-50 \mu \mathrm{eq} \mathrm{I}^{-1}$

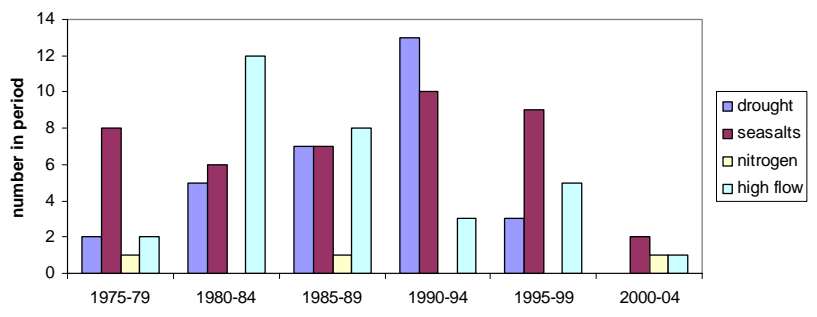

Fig. 11. Main driver of episodes at Birkenes 1975-2004 by 5-year period.

$2 \mathrm{~m} \mathrm{~s}^{-1}$ increase in surface wind. Future climate change may entail increased frequency and severity of storms with both high wind and high amounts of precipitation.

The statistical relationship between flow $(\mathrm{Q})$ and minimum ANC can be used to predict ANC depression given mean ANC and Q (Fig. 5). If future climate entails increased frequency of storms with high precipitation, then high flow acid episodes can be expected to become more frequent.

The role of $\mathrm{NO}_{3}$. A major source of major uncertainty seems to be $\mathrm{NO}_{3}$. During the 30 -year record at Birkenes its role has apparently not changed. $\mathrm{N}$ deposition has not changed much, mean $\mathrm{NO}_{3}$ concentrations show no clear time trend (Fig. 1), and the catchment retains $>90 \%$ of the incoming $\mathrm{N}$. Over the 30 -years there have been several $\mathrm{NO}_{3}$ peaks as large as $100 \mu \mathrm{eq} 1^{-1}$, certainly more than sufficient to drive ANC depression well below the threshold of $-50 \mu \mathrm{eq} 1^{-1}$. The $\mathrm{NO}_{3}$ peaks were associated with snowmelt or heavy rain events in the autumn. Even if the catchment recovers such that runoff achieves mean $\mathrm{ANC}>0 \mu \mathrm{eq} 1^{-1}, \mathrm{NO}_{3}$-driven episodes could potentially cause ANC depressions below the threshold for biological damage. Furthermore, if future climate change entails a warmer climate, potentially stored $\mathrm{N}$ in the catchment soils could be released due to increased mineralisation of soil organic matter, as was found in the CLIMEX experiment conducted at Risdalsheia, about $10 \mathrm{~km}$ from Birkenes (van Breemen et al., 1998; Wright, 1998).

Biological relevance. This analysis of episodes at Birkenes used the threshold of ANC-50 $\mu \mathrm{eq} \mathrm{l}^{-1}$. This value was chosen simply to illustrate the effect of recovery on the frequency and causes of episodes in the 30-year record. To have biological relevance the threshold must be much higher. A sustainable population of brown trout in the Birkenes stream probably requires yearly $\mathrm{ANC}>0 \mu \mathrm{eq} \mathrm{l}^{-1}$. A survey of brown trout population status and ANC in about 1000 Norwegian lakes showed that at ANC 0 the probability of a sparse or good population was about 50\% (Lien et al., 1996). The relationship between minimum ANC and mean ANC (Fig. 3) indicates that the threshold for biologicallydamaging episodes at Birkenes probably should be above $-30 \mu \mathrm{eq} 1^{-1}$. 


\section{Conclusions}

The frequency, severity and duration of acid episodes in streamwater at Birkenes have diminished since about 1990 due to chemical recovery following reduced deposition of sulphur. Acid episodes at Birkenes are associated with one or more conditions such as high flow, first runoff after drought, storms with high atmospheric inputs of seasalts, and snowmelt. Several of the causes of acid episodes at Birkenes are clearly related to climate and independent of deposition of $\mathrm{S}$ and $\mathrm{N}$ compounds.

$\mathrm{SO}_{4}$ is diminishing in importance as a driver of acid episodes; the magnitude of the $\mathrm{SO}_{4}$ pulse following drought has declined in recent years. Acid episodes caused by snowmelt are infrequent at Birkenes because of its mild winters due to proximity to the coast and low elevation. Seasalt deposition is a major driver of episodic ANC depression at Birkenes. Approximately one-third of all the ANC $<-50 \mu \mathrm{eq}^{-1}$ episodes during the period 1980-2004 were driven primarily by seasalts. The drivers high flow and seasalts have not diminished in intensity, and thus caused acid episodes throughout the record, also in recent years.

Future changes in climate can affect the frequency and severity of episodes. Future climate change may entail increased frequency and severity of storms with both high wind and high amounts of precipitation.

A major source of major uncertainty seems to be $\mathrm{NO}_{3}$. At Birkenes the $\mathrm{NO}_{3}$ peaks were associated with snowmelt or heavy rain events in the autumn. Even if the catchment recovers, $\mathrm{NO}_{3}$-driven episodes could potentially cause ANC depressions below the threshold for biological damage. Furthermore, if future climate change entails a warmer climate, potentially stored $\mathrm{N}$ in the catchment soils could be released due to increased mineralisation of soil organic matter.

Acknowledgements. This work was supported in part by the Eurolimpacs project (the Commission of European Communities GOCE-CT-2003-505540), the Research Council of Norway, the Norwegian State Pollution Control Authority, and the Norwegian Institute for Water Research. I thank C. Evans (CEH) for inspiring this analysis, my colleagues at NIVA T. Larssen, J. Moe, B. L. Skjelkvåle, and H. de Wit for helpful discussion, and T. Høgåsen (NIVA) for work with the database.

Edited by: P. Dillon and R. F. Wright

\section{References}

Aas, W., Solberg, S., Berg, T., Manø, S., and Yttri, K. E.: Monitoring of long-range transported polluted air and precipitation, Atmospheric deposition 2003, 903/2004, The Norwegian State Pollution Control Authority, Oslo, Norway, 2004 (in Norwegian).

Christophersen, N., Neal, C., Hooper, R. P., Vogt, R. D., and Andersen, S.: Modelling streamwater chemistry as a mixture of soil water end-members; A step towards second generation acidification models, J. Hydrol., 116, 307-320, 1990.

Christophersen, N., Seip, H. M., and Wright, R. F.: A model for streamwater chemistry at Birkenes, Norway, Water Resour. Res. 18, 977-996, 1982.

Christophersen, N. and Wright, R. F.: Sulfate budget and a model for sulfate concentrations in streamwater at Birkenes, a small forested catchment in southernmost Norway, Water Resour. Res., 17, 377-389, 1981.

Davies, T. D., Tranter, M., Wigington, P. J., and Eshleman, K. N.: "Acidic episodes" in surface waters in Europe, J. Hydrol., 132, 25-69, 1992.

Dillon, P. J., Molot, L. A., and Futter, M.: The effect of El Nino-related drought on the recovery of acidified lakes, Environ. Monit. Assess., 46, 105-111, 1997.

Eimers, M. C., Watmough, S. A., Buttle, J. M., and Dillon, P. J.: Drought-induced sulphate release from a wetland in southcentral Ontario, Environ. Monit. Assess., 127, 399-407, 2007, 2007.

Evans, C., Reynolds, B., Hinton, C., Hughes, S., Norris, D., Grant, G., and Williams, B.: Effects of decreasing acid deposition and climate change on acid extremes in an upland stream, Hydrol. Earth Syst. Sci., 12, this special issue, 2008.

Evans, C. D., Cullen, J., Alewell, C., Kopácek, J., Marchetto, A., Moldan, F., Prechtel, A., Rogora, M., Veselý, J., and Wright, R. F.: Recovery from acidification in European surface waters, Hydrol. Earth Syst. Sci., 5, 283-298, 2001, http://www.hydrol-earth-syst-sci.net/5/283/2001/.

Heath, R. H., Kahl, J. S., Norton, S. A., and Fernandez, I. J.: Episodic acidification caused by the seasalt effect in coastal Maine streams, Water Resour. Res., 28, 1081-1088, 1992.

Hindar, A., Henriksen, A., Tørseth, K., and Semb, A.: Acid water and fish death, Nature, 372, 327-328, 1994.

Johannessen, M. and Henriksen, A.: Chemistry of snowmelt water: changes in concentration during melting, Water Resour. Res., 14, 615-619, 1978.

Johannessen, M., Skartveit, A., and Wright, R. F.: Streamwater chemistry before, during and after snowmelt, 224-225, in: Ecological Impact of Acid Precipitation, edited by: Drabløs, D. and Tollan, A., SNSF project, Ås, Norway, 1980.

Langan, S. J.: Sea-salt induced streamwater acidification, Hydrol. Processes, 3, 25-41, 1989.

Laudon, H. and Bishop, K.: Episodic stream water $\mathrm{pH}$ decline during autumn storms following a summer drought in northern Sweden, Hydrol. Processes, 16, 1725-1733, 2000.

Laudon, H. and Bishop, K. H.: Quantifying sources of acid neutralisation capacity depression during spring flood episodes in northern Sweden, Environ. Pollut., 105, 427-435, 1999.

Laudon, H. and Bishop, K. H.: The rapid and extensive recovery from episodic acidification in northern Sweden due to declines in SO4-2 deposition, Geophys. Res. Lett., 29, 1594, doi:10.1029/2001GL014211, 2002.

Laudon, H., Westling, O., and Bishop, K. H.: Cause of pH decline in stream water during spring melt runoff in northern Sweden, Can. J. Fisheries Aquatic Sci., 57, 1888-1900, 2000.

Leivestad, H. and Muniz, I. P.: Fish kill at low $\mathrm{pH}$ in a Norwegian river, Nature, 259, 391-392, 1976.

Lien, L., Raddum, G. G., Fjellheim, A., and Henriksen, A.: A critical limit for acid neutralizing capacity in Norwegian surface wa- 
ters, based on new analyses of fish and invertebrate responses, Sci. Total Environ., 177, 173-193, 1996.

Mulder, J., Christophersen, N., Kopperud, K., and Fjeldal, P. H.: Water flow paths and the spatial distribution of soils as a key to understanding differences in streamwater chemistry between three catchments (Norway), Water Soil Air Pollut., 81, 67-91, 1995.

Neal, C., Christophersen, N., Neal, R., Smith, C. J., Whitehead, P. G., and Reynolds, B.: Chloride in precipitation and streamwater for the upland catchment of river Severn, mid-Wale; some consequences for hydrochemical models, Hydrol. Processes, 2, 155-165, 1988.

Overrein, L., Seip, H. M., and Tollan, A.: Acid precipitation - Effects on forest and fish. Final report of the SNSF-project 19721980, FR 19-80, SNSF project, Ås, Norway, 1980.

Reuss, J. O. and Johnson, D. W.: Acid Deposition and the Acidification of Soils and Waters, Springer Verlag, New York, 1986.

Schiff, S. L., Spoelstra, J., Semkin, R. G., and Jeffries, D. S.: Drought induced pulses of $\mathrm{SO}_{4}^{2-}$ from a Canadian shield wetland: use of $\delta^{34} \mathrm{~S}$ and $\delta^{18} \mathrm{O}$ in $\mathrm{SO}_{4}^{2-}$ to determine sources of sulfur, Appl. Geochem., 20, 691-700, 2005.

SFT: The Norwegian monitoring programme for long-range transported air pollutants, Annual report - Effects 2005, TA2205/2006, The Norwegian Pollution Control Authority (SFT), Oslo, 2006.

Skartveit, A.: Wet scavenging of sea-salts and acid compounds in a rainy coastal area, Atmos. Environ., 16, 2715-2724, 1982.
Skartveit, A. and Gjessing, Y. T.: Chemical budgets and chemical quality of snow and runoff during spring snowmelt, Nordic Hydrol., 10, 141-154, 1979.

Skjelkvåle, B. L., Evans, C. D., Larssen, T., Hindar, A., and Raddum, G. G.: Recovery from acidification in European surface waters: A view to the future, Ambio, 30, 170-175, 2003.

UNECE: The 1999 Protocol to Abate Acidification, Eutrophication and Ground-level Ozone, Document ECE/EB.AIR, United nations Economic Commission for Europe, New York and Geneva, 1999.

van Breemen, N., Jenkins, A., Wright, R. F., Arp, W. J., Beerling, D. J., Berendse, F., Beier, C., Collins, R., van Dam, D., Rasmussen, L., Verburg, P. S. J., and Wills, M. A.: Impacts of elevated carbon dioxide and temperature on a boreal forest ecosystem (CLIMEX project), Ecosystems, 1, 345-351, 1998.

Wigington, P. J., Davies, T. D., Tranter, M., and Eshleman, K. N.: Comparison of episodic acidification in Canada, Europe and the United States, Environ. Pollut., 78, 29-35, 1992.

Wigington, P. J., DeWalle, D. R., Murdoch, P. S., Kretser, W. A., Simonin, H. A., Van Sickle, J., and Baker, J. P.: Episodic acidification of small streams in the northeastern United States: ionic controls of episodes, Ecol. Appl., 6, 389-407, 1996.

Wright, R. F.: Effect of increased $\mathrm{CO}_{2}$ and temperature on runoff chemistry at a forested catchment in southern Norway (CLIMEX project), Ecosystems, 1, 216-225, 1998.

Wright, R. F., Norton, S. A., Brakke, D. F., and Frogner, T.: Experimental verification of episodic acidification of freshwaters by sea salts, Nature, 334, 422-424, 1998. 